\title{
Current Findings on Gut Microbiota Mediated Immune Modulation against Viral Diseases in Chicken
}

\author{
Muhammad Abaidullah ${ }^{1,+}$, Shuwei Peng ${ }^{1,+}$, Muhammad Kamran ${ }^{2} \mathbb{D}, X$ Song $^{1}$ and \\ Zhongqiong Yin ${ }^{1, *}$ \\ 1 Natural Medicine Research Center, College of Veterinary Medicine, Sichuan Agricultural University, \\ Chengdu 611130, China \\ 2 Queensland Alliance for Agriculture and food Innovation, The University of Queensland, \\ Brisbane 4072, Australia \\ * Correspondence: yinzhongq@163.com \\ + Those authors contribute equally to the work.
}

Received: 18 June 2019; Accepted: 19 July 2019; Published: 25 July 2019

\begin{abstract}
Chicken gastrointestinal tract is an important site of immune cell development that not only regulates gut microbiota but also maintains extra-intestinal immunity. Recent studies have emphasized the important roles of gut microbiota in shaping immunity against viral diseases in chicken. Microbial diversity and its integrity are the key elements for deriving immunity against invading viral pathogens. Commensal bacteria provide protection against pathogens through direct competition and by the production of antibodies and activation of different cytokines to modulate innate and adaptive immune responses. There are few economically important viral diseases of chicken that perturb the intestinal microbiota diversity. Disruption of microbial homeostasis (dysbiosis) associates with a variety of pathological states, which facilitate the establishment of acute viral infections in chickens. In this review, we summarize the calibrated interactions among the microbiota mediated immune modulation through the production of different interferons (IFNs) ILs, and virus-specific $\operatorname{IgA}$ and $\operatorname{IgG}$, and their impact on the severity of viral infections in chickens. Here, it also shows that acute viral infection diminishes commensal bacteria such as Lactobacillus, Bifidobacterium, Firmicutes, and Blautia spp. populations and enhances the colonization of pathobionts, including E. coli, Shigella, and Clostridial spp., in infected chickens.
\end{abstract}

Keywords: chicken; gut-microbiota; commensal; pathobionts; Lactobacillus; Bifidobacterium; E. coli; Shigella

\section{Introduction}

Beginning from the first moment of birth, every single uncovered surface (for example the skin, mouth, vagina, and gut) in warm-blooded animals becomes step by step colonized by a wide assortment of microorganisms, which are known as the microbiota [1-3]. Although we have large data sets, extensive research is still required to understand more about physiological functions and dynamics of the microbiota. It is more important in pathological conditions and when microbiota performs its function in the gut as digestion of nutrients and the main producer of many vitamins [4]. During a lifetime, microbiota evolves with the host in composition with nutrition, probiotics and nutraceuticals such ovotransferrin are the main components that maintain the diversity of gastrointestinal tract (GIT) microbiota [5-7]. GIT microbiota has many effects on digestion of nutrients, immunity development, and shielding hosts from pathogens $[3,8,9]$. Intestinal microbiota affects both local and systemic immune responses [10,11]. Germ-free mouse models are extensively used to study microbiota functions of 
shaping adaptive and innate immune responses [11,12]. Various bacterial species have been recognized that maintain host homeostasis. For instance, small molecules such as bacterial polysaccharide (PSA) from Bacteroides fragilis have given proof that symbiotic microbes and its products communicate with and shape the immune response, particularly in the transformation of CD4+ and Foxp3+ [13]. Segmented filamentous bacteria induce the Th17 cells [14] and Clostridial cluster XIVa and IV induce the colonic Tregs [15]. Gut health improves the health of the poultry flock by enhancing its performance and regulating $\mathrm{T}$ cells in the intestine $[14,16]$. Chicken intestine is inhabited by a variety of commensal microbiota [9]. Of those, Firmicutes, Proteobacteria, and Bacteroidetes are the most important ones [17]. Bird development is severely affected if the gut microbiota or mucosal barrier of the intestine is disturbed [18]. The GI tract has a very reactive environment and pathogens can disrupt the host and its microflora homeostasis, which is called dysbiosis and leads to mucosal infections [19]. Bacterial dysbiosis has been connected to inflammation and changes in immune functions [20]. Changes in the microbial community affects type I IFNs and inflammatory responses of the host [21,22]. Many diseases disturb the stability of intestinal microflora [23-25]. Chickens with dysbiosis are more prone to bacterial infection [26]. Studies reflect connections between gut microbiota and distal organs in regulatory functions like gut-lung, gut-brain, gut-skin, and gut-liver axes, which play an important role in many infectious and chronic diseases [27]. In some studies, it is reported that gut microbiota can regulate the antiviral immune response [28] through metabolites such as short-chain fatty acids (SCFAs). The role of SCFAs is well studied in mouse models that show a reduction in inflammatory symptoms by utilizing SCFAs and T regulatory cell suppression in allergic diseases of airways [29]. Recently, there is growing interest to learn the mechanism involved in gastrointestinal tract (GIT) microbiota and infectious and noninfectious disease interaction. GIT microbiota plays a pivotal role to regulate and induce host responses against various pathogens including viruses [30-32], bacteria [33-35], and fungi [36]. Trans-kingdom associations of viruses and microbiota suggests important role of microbiota in virus replication, development, and progression [37]. Some of the potential mechanisms involved in gut microbiota mediated immunity to pathogens include those involving pattern-recognition receptors (PRRs) such as Toll-like receptors $[30,33,34]$ and nucleotide-binding oligomerization domain-like receptors [38] that recognize microbial-associated molecular patterns (MAMPs).

In the current study, we focused only on the interaction between gut microbiota and viral infections and their impact on immune regulations in chicken. At present only four viral diseases (Avian influenza, Marek's, Infectious Bursal Disease (IBD), and Newcastle Disease (ND)) re reported with their connections between gut microbiota and immune modulations.

Avian influenza virus (AIV) is a negative sense single-stranded virus having a segmented genome that causes respiratory illness, gastroenteritis, and diarrhea [39]. There are a number of strains of AI and the H9N2 strain is the biggest threat to public health due to its ability to replicate in mammalian tissue [40-42], and previous reassortant isolates of Highly pathogenic avian influenza (HPAI) in humans were shown to carry internal genes from avian H9N2 viruses $[40,43,44]$. Studies confer that gut microbiota elicit the immune response against the influenza virus and they depicts that gut microbiota regulation is a potential source of treatment for respiratory diseases $[28,45]$. Due to the high mutation rate of influenza viruses, contemporary lack of a reliable antiviral treatment and consistently effective vaccine emphasize the development of novel management and prevention strategies. The gut-lung axis alliance acts as an important mark for the development of such strategies as it is extensively used in many airway diseases. A correlation among gut microbiota diversity and influenza was observed in mice [30]. It was reported that dysbiosis in chicken gut microbiota resulted in higher cloacal and oropharyngeal shedding of avian influenza H9N2 in chickens, which was also linked with compromised type I interferon (INF) expression [41]. Marek's disease (MD) is a contagious, globally prevalent viral disease of chicken [46] caused by Marek's disease virus (MDV) or Gallid alpha herpesvirus 2 [47] that mainly targets lymphoid organs such as spleen, bursa of Fabricius, and thymus, thereby infecting B and T cells [48,49]. MDV causes up to $100 \%$ mortality $[50,51]$. The pathological lesions of MDV include mononuclear infiltration of the gonads, peripheral nerves, various viscera, 
iris, muscles, and skin. Infected chickens develop CD4+ T-cell tumors in visceral organs and enlarged nerves resulting in paralysis, blindness, and eventually death [52-57]. MDV also causes chicken gut microbiota dysbiosis [58].

Infectious bursal disease (IBD) is a viral disease of chicken caused by infectious bursal disease virus (IBDV) [59-62]. IBDV is a non-enveloped virus that belongs to the genus Avibirnavirus and the Birnaviridae family [62-66]. IBDV infection causes immunosuppression, which leads to gut-associated secondary infection, resulting in high mortality rates in chicken [67-69]. IBDV causes severe damage to the bursa of Fabricius and affects IgM+ B cell production [61,70].

Newcastle disease virus (NDV) is a contagious disease of poultry caused by highly pathogenic strain avian paramyxovirus type 1 (APMV-1) serotype belonging to the genus Avulavirus, subfamily Paramyxovirinae, and family Paramyxoviridae [71,72]. It has been reported that NDV infection causes dysbiosis of gut microbiota of chicken, which increases the severity of disease [73]. Despite these rapid advances, there is little information available on the impact of acute viral infection on the quantity, composition, and kinetics of commensal gut microbiota in the chicken.

\section{Avian Influenza Virus}

Avian influenza virus (AIV) subtype H9N2 has tropism for many tissues, including tissues of GIT and the upper respiratory tract of chicken. AIV enters the body through the mucosa of the respiratory tract and GIT [74]. Recent studies have revealed that commensal gut microbiota play a decisive role in viral pathogenesis to regulate the immune response against influenza virus [28,45]. In contrast, dysbiosis of gut microbiota in chicken elicit the severity of disease [39]. The health and diversity of gut microbiota are key factors to diminish the influenza virus infection [28].

\section{Commensal Bacteria Elicit Immunity}

Commensal intestinal microbiota play a crucial role in the health and disease of the chicken by eliciting an immune response against infection and virus clearance. Different commensal bacteria have their own unique role against viral infection by modulating diverse immune mechanisms as reported in Table 1 [75]. The depletion of these bacteria augment the influenza virus disease course and delay the cloacal and oropharyngeal shedding in H9N2 infected chickens as compared to undepleted groups [41,76]. Type-I IFNs comprised of IFN- $\alpha$ and IFN- $\beta$ are integral parts of the antiviral innate immune response in virus-infected cells and interrupt the viral life cycle by degradation of virus nucleic acids or inhibition of viral gene expression [77-79]. Along with IFNs, IL-22 interactively inhibits intestinal viral infections [80] by impeding GIT tissue degeneration, escalating cell proliferation, and modulating inflammation [81]. The expression level of IFN- $\alpha$, IFN- $\beta$, and IL-22 in antibiotic-treated along with AIV infected chickens was markedly diminished compared to undepleted AIV infected chicks. The expression level of type-I IFNs and IL-22 in the antibiotic-treated group was restored to the undepleted group by Lactobacillus and fecal microbial transplantation (FMT) [41,76]. Different bacterial genera in GIT modulate the expressions of different AIV antiviral cytokines. IFN- $\alpha$, IFN- $\beta$, and IL-22 expression were positively correlated with Collinsella, Faecalibacterium, Oscillibacter, Holdemanella, Pseudoflavonifractor, Anaerotruncus, Butyricoccus, and Bifidobacterium while these were negatively correlated with Clostridium cluster-XI, Escherichia, and Shigella species as shown in Figure 1 [41]. Strong recovery was observed in histomorphological structures and the general architecture of the ileum in AIV infected chickens after fecal microbial transplantation (FMT), and probiotic (PROB) supplementation [41]. 
Table 1. Comparison between commensal and pathogenic gut-microbiota mediated immune modulation in AIV, IBDV, MDV, and NDV infected chickens.

\begin{tabular}{|c|c|c|c|c|}
\hline \multirow{2}{*}{ Virus } & \multicolumn{2}{|c|}{ Control Group } & \multicolumn{2}{|c|}{ Infected Group } \\
\hline & Commensals & Effector Molecules and Outcomes & Pathogens & Effector Molecules and Outcomes \\
\hline AIV & $\begin{array}{l}\text { Collinsella, Faecalibacterium, } \\
\text { Oscillibacter, Holdemanella, } \\
\text { Pseudoflavonifractor, Anaerotruncus, } \\
\text { Butyricoccus, and Bifidobacterium }\end{array}$ & $\begin{array}{l}\text { Increase IFN- } \alpha \text {, IFN- } \beta \text {, and IL-22 and } \\
\text { antimicrobial peptides such as MUC, TFF, } \\
\text { ZO, and tight junction proteins comprised } \\
\text { of claudins, occludin, and zona occludens } \\
\text { mRNA expressions }\end{array}$ & $\begin{array}{l}\text { Proteobacteria Clostridium } \\
\text { cluster XI, Escherichia, Shigella, } \\
\text { Salmonella, Vampirovibrio, } \\
\text { Clostridium cluster XIVb, } \\
\text { and genus Ruminococcus }\end{array}$ & $\begin{array}{l}\text { Downregulate the IFN- } \alpha \text {, IFN- } \beta \text {, and IL-22 } \\
\text { secretion and antimicrobial peptides such } \\
\text { as MUC, TFF, ZO, and tight junction } \\
\text { proteins comprised of claudins, occludin, } \\
\text { and zona occludens mRNA expressions } \\
\text { also enhance the secretions of } \\
\text { proinflammatory cytokines IFN- } \gamma \text {, IL-17A, } \\
\text { IL-6, and IL-1B and produce inflammation }\end{array}$ \\
\hline \multirow{3}{*}{ IBDV } & Clostridium XIVa & $\begin{array}{l}\text { Induce } \mathrm{T} \text { regulatory cells to produce } \\
\text { anti-inflammatory cytokines }\end{array}$ & Desulfovibrionaceae & $\begin{array}{l}\text { Produce hydrogen sulfides and cause } \\
\text { inflammation }\end{array}$ \\
\hline & Faecalibacterium & $\begin{array}{l}\text { Enhance butyrate shortchain fatty acids } \\
\text { (SCFA) and suppress the inflammation }\end{array}$ & Campylobacter jejuni & $\begin{array}{l}\text { Inhibit butyrate SCFA production cause } \\
\text { inflammation of GIT }\end{array}$ \\
\hline & Probiotics & $\begin{array}{l}\text { Increase immunoglobulins, FCR body } \\
\text { weight gain }\end{array}$ & $\begin{array}{l}\text { Salmonella typhimurium and } \\
\text { Campylobacter jejuni }\end{array}$ & Decreased IgG and IgA production \\
\hline \multirow{2}{*}{ MDV } & Firmicutes & $\begin{array}{l}\text { Induce T regulatory cells to produce } \\
\text { anti-inflammatory cytokines }\end{array}$ & $\begin{array}{l}\text { Pathogenic Lactobacillus spp., } \\
\text { Proteobacteria }\end{array}$ & $\begin{array}{l}\text { Suppress the T regulatory cells stimulation } \\
\text { produce inflammation }\end{array}$ \\
\hline & $\begin{array}{l}\text { Blautia spp. and Faecalibacterium } \\
\text { spp. }\end{array}$ & $\begin{array}{l}\text { Produce succinate and lactate and provide } \\
\text { energy and reduce inflammation }\end{array}$ & Streptococcus spp. & Septicemia, peritonitis, and endocarditis \\
\hline NDV & Paenibacillus and Enterococcus & Antimicrobial peptides & $\begin{array}{l}\text { Rhodoplanes, Clostridium, } \\
\text { and Epulopiscium }\end{array}$ & Cause local mucosal infection \\
\hline
\end{tabular}




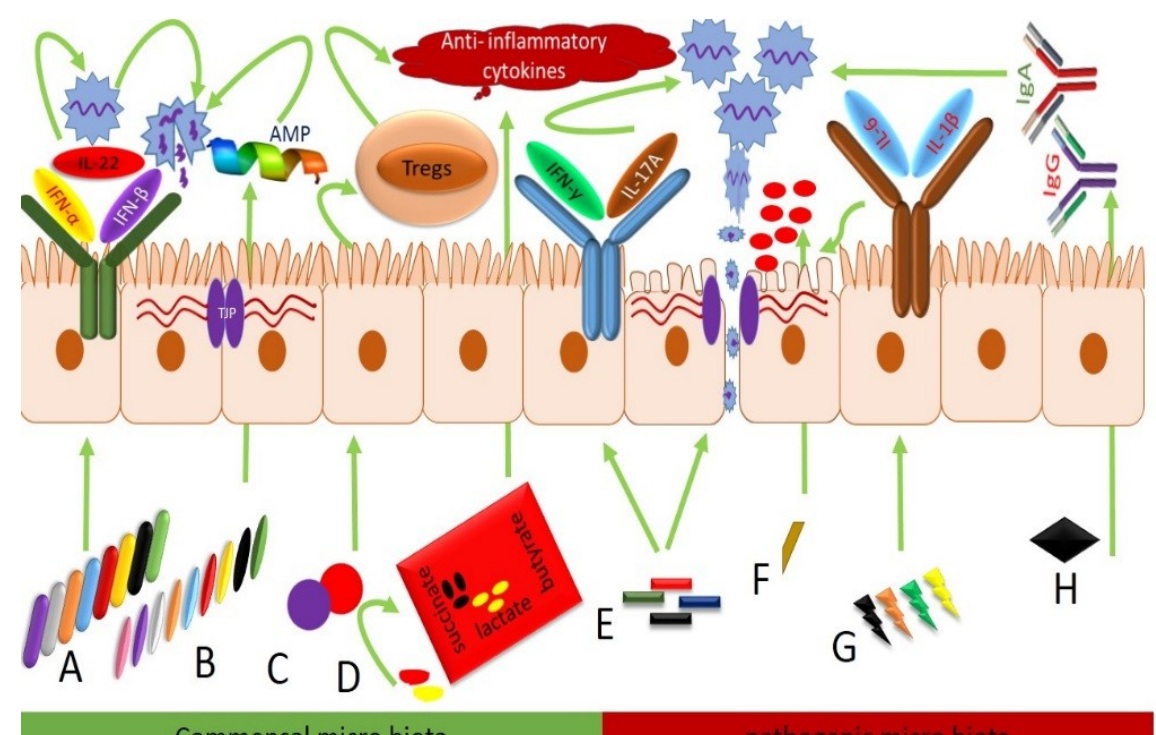

Commensal micro biota

Figure 1. Regulation of different immune mechanisms by intestinal microbiota in AIV, IBDV, MDV, and NDV virus infected broiler chickens. (A) Collinsella, Faecalibacterium, Oscillibacter, Holdemanella, Pseudoflavonifractor, Anaerotruncus, Butyricoccus, and Bifidobacterium enhance the IFN- $\alpha$, IFN- $\beta$, and IL-22 secretions, which control the virus replication by degrading the virus nucleus, as well as virus replication genes, and repair mucosal tissue damage. (B) Bacteroides, Candidatus, SMB53, Parabacteroides, Lactobacillus, Paenibacillus, Enterococcus, and Streptococcus spp. promote the antimicrobial peptides such as MUC, TFF, ZO, and tight junction proteins comprised of claudins, occludin, and zona occludens mRNA expressions and inhibit pathobiont colonization and translocation and suppress inflammation. (C) Clostridium XlVa and Firmicutes induce the T regulatory cells, which produce anti-inflammatory cytokines and suppress inflammation. (D) Faecalibacterium and Blautia spp. enhance butyrate succinate and lactate production, which provide energy and reduce inflammation. (E) Cluster XI, Salmonella, Escherichia, and Shigella are pathobionts. These pathogens decrease IFN- $\alpha$, IFN- $\beta$, and IL-22 antimicrobial peptides such as MUC, TFF, ZO, and tight junction proteins comprised of claudins, occludin, and zona occludens mRNA expressions, increase the IFN- $\gamma$, IL-17A secretions that cause the mucosal inflammation, tissue damage Increased virus replication and fecal shedding. (F) Desulfovibrionaceae produce hydrogen sulfides and produce inflammation of mucosa. (G) Vampirovibrio, Clostridium cluster XIVb, and genus Ruminococcus induce the proinflammatory cytokines IL-6 and IL-1B, which produce GIT inflammation and leads to increased viral replication. (H) Salmonella typhimurium, Campylobacter jejuni decrease viral specific IgG and IgA production, which results in more viral shedding.

\section{AIV Mediated Dysbiosis in Commensal Microbiota}

Type-I INFs and IFN- $\gamma$ are effective antiviral agents in H2N9 AIV infection $[21,22,79,82-84]$ that enhance inflammation and mucosal tissue degeneration, and disrupt the commensal gut microbiota diversity, which leads to an increased pathogenic bacterial population and results in secondary bacterial infections [21,85]. Previously, in H9N2 AIV infected chickens, elevated levels of IFN- $\gamma$ and IL-17A were observed, which caused the dysbiosis of commensal gut microbiota and decreased the number of lactic acid producing bacteria such as Lactobacillus, Enterococcus, and Streptococcus due to an increased population of pathogenic Proteobacteria [86], comprised of Salmonella, E. coli, Klebsiella, and Shigella, which produce inflammation in GIT as described in Table 1 [87]. Similar results were also observed in highly pathogenic influenza virus infected mice and increased production of IFN- $\gamma$ and IL-17A led to intestinal micro flora dysbiosis [88]. An increased growth of pathobionts including Vampirovibrio, Clostridium cluster-XIVb, and genus Ruminococcus was observed in AIV infected broiler chicks [79]. These pathobionts produce proinflammatory cytokines IL-6 and IL-1B [87]. The mucosal epithelium of GIT plays a basic role in digestion and absorption of nutrients acting as a first line of defense against pathogens and preventing the entry of pathogens into the body of the host $[89,90]$. Damage of the 
GIT mucosa promotes the translocation of pathogens into body and causes systemic infection [91,92]. Antimicrobial peptides including mucins (MUC), endogenous trefoil (TFF), and tight junction proteins (Claudins, Occludin, and Zona Occludens (ZO)) inhibit pathogenic microbe infection and keep the permeability of the intestinal mucosa intact [93-99]. In recent studies, it was reported that in H9N2 AIV infected chickens, the expressions of MUC, TFF, Claudins, Occludin, and ZO were significantly reduced and produced inflammation of mucosal epithelium, which led to secondary bacterial infection due to invasion of E.coli as presented in Figure 1 [85,86].

\section{Infectious Bursal Disease Virus (IBDV)}

IBDV is an immunosuppressive disease of poultry [67,69], mainly affecting the primary lymphoid organs comprised of thymus and bursa of Fabricius, as well as gut-associated lymphoid tissues (GALT) [100], which act as the first line of defense against invading pathogens and establish systemic immune responses [101]. The immune system is an important contributor for regulating the microbial composition; likewise, it has been also reported that microbiota shapes the immunity [11]. Immunosuppressive diseases impact the development of the intestinal immunity and microbial composition and consequently modify the gut barrier [3,102]. IBDV causes acute infection between two to five days post inoculation [103], during which peak production of proinflammatory cytokines and IBDV replication has been reported [104], which causes gut microbiota dysbiosis, leading to lower abundance of commensals Clostridium XIVa [105]. Previously, it was reported that these commensals induce the colonic $\mathrm{T}$ regulatory cells to suppress the production of the proinflammatory cytokines [15,106-108]. In IBDV infected birds an increased abundance of sulphur reducing Desulfovibrionaceae was observed and these hydrogen sulfides are toxic to mucosal tissue, which leads to severe inflammation of GIT as described in Table $1[105,109,110]$. Faecalibacterium is an important butyrate-producing bacteria in the cecum of the chicken [111]. Higher numbers of Faecalibacterium are deleterious for Campylobacter jejuni replication since butyrate may inhibit the replication of Campylobacter jejuni [112]. Recently, a lower abundance of Faecalibacterium and higher fecal shedding of Campylobacter jejuni in chickens that were co-infected with IBDV and Campylobacter jejuni was observed as compared to those infected only with Campylobacter jejuni $[113,114]$. IgA is the main immunological defense against invading pathogens in the gut and it also regulates the microbial diversity in the intestine [115]. IBDV depletes B cell production in the lamina propria of the intestine and cause enteritis [116], which leads to a decrease in IgA and IgG mediated humoral immunity against Salmonella typhimurium and Campylobacter jejuni, resulting in increased shedding of these pathogens in feces of IBDV infected chickens as shown in Figure $1[113,117-119]$. Contrarily to the pathobionts mediated immunosuppressive effects IBDV, it was also reported that probiotic supplementation in IBDV infected broiler chicks enhanced the body weight gain, feed conversion ratio, and antibody titers, and decreased the morbidity and mortality against IBDV infection [120].

\section{Marek's Disease Virus}

Marek's disease (MD) is a contagious and globally prevalent viral disease [46]. Marek's disease virus (MDV) suppresses the immune system and produces inflammatory neurological syndromes, which lead to paralysis and causes 100\% mortality in chickens [49,50,121]. MDV affects the immune system, especially B and T lymphocytes [122]. The pattern of the disease to alter the immune system is probably due to the established link between the microbiome and immune system. MDV pathogenesis causes dysbiosis in chicken gut microbiota, which leads to enrichment of certain pathogenic bacterial genera in the cecum [123]. Ovotransferrin, which is a nutraceutical, has anti MDV properties and it enhances the Firmicutes population and diminishes the Proteobacteria [5,124-126]. Members of phylum Firmicutes regulate the inflammation by producing anti-inflammatory cytokines through regulatory $\mathrm{T}$ (Treg) cell activation as discussed in Table 1 [127]. MDV during the proliferative phase at 28-35 days of its life cycle [49], reduces the Firmicutes population and provides a favorable environment for the four different opportunistic pathogenic Lactobacillus spp. and Proteobacteria colonization 
due to inflammation of the intestinal mucosa [123,128]. Blautia is a Gram-positive staining coccoid or oval-shaped, non-motile bacterium that produces metabolites such as succinate and lactate by the degradation of polysaccharides and provides energy to the host $[129,130]$. In recent studies, an increased Faecalibacterium spp. and Blautia spp. colonization in control chicks was reported as compared to their MDV infected counterparts, having more Streptococcus spp. [128], and these are opportunistic pathogens that develop septicemia, peritonitis, and endocarditis in chicken [131].

\section{Newcastle Disease Virus (NDV)}

Newcastle disease is a contagious disease of chicken [71], which produces hemorrhages and necrosis of the respiratory tract and the digestive system [132], leading to high morbidity and mortality in chicken [133]. NDV infection induces interferon production [134], which increases the lethality of bacterial endotoxin [135] and causes the disproportion of intestinal microbiota in chickens [73]. Rhodoplanes are pathogens that produce febrile conditions and cause local infection [136]. In the cecum of NDV infected chickens, an increased abundance of pathogenic Rhodoplanes, Clostridium, and Epulopiscium was detected, which causes the depletion of Paenibacillus and Enterococcus [137]. Paenibacillus are commensal bacteria that produce antimicrobial substances against a wide range of microorganisms such as fungi, plant pathogenic bacteria, and anaerobic pathogens including Clostridium botulinum as shown in Figure $1[138,139]$.

\section{Conclusions}

In conclusion, we have reported here that commensal bacteria including Lactobacillus, Bifidobacterium, Firmicutes, Faecalibacterium, Blautia spp., and Clostridium XIVa play a key role in viral disease prevention and treatment, through competition, by inhabiting the mucosal surface of GIT. Microbiota helps the host in food digestion to produce SCFAs as an energy source. These SCFAs regulate the different anti-viral immune mechanisms by the production of IFN- $\alpha$, IFN- $\beta$, and T regulatory cells, which stimulate secretions of anti-inflammatory cytokines such as IL-22 and promote the humoral immune response by the production of IgA and IgG antibodies to control the severity of virus infection in chicken. Contrarily, it is also observed that these viral infections cause dysbiosis of intestinal microbiota and enhance gut pathobiont colonization such as Proteobacteria, Clostridium cluster XI, Clostridium cluster XIVb, Escherichia, Shigella, Salmonella, Campylobacter jejuni, Streptococcus spp., Rhodoplanes, Vampirovibrio, Desulfovibrionaceae, and genus Ruminococcus. These pathobionts augment the severity of virus infections by suppression of anti-inflammatory cytokines, $\mathrm{T}$ regulatory cells, and B lymphocytes immunoglobulins production and enhance proinflammatory cytokines comprised of IL-17A and IFN- $\gamma$ production. Due to the constant emergence of new viral strains that lead to reduced cross-protection by vaccinations against viral infections, there is, therefore, still a need for the development of a more reliable way to solve this riddle. As we observed, the change of a single bacterial genus can have a direct impact on immune system regulation, and supplementation of these specific commensal probiotics in a specific virus infection could be an alternative to restore the innate and adaptive immune mechanisms and combat these severe economic losses in the poultry industry.

Author Contributions: Conceptualization, M.A.; Methodology, S.P.; Software, M.A. and V.X.S.; Investigation, M.K.; Data Curation, S.P.; Original Draft Preparation, M.A.; Writing-Review and Editing, X.S. and M.K.; Visualization, Supervision, Project Administration, and Funding Acquisition, Z.Y.

Acknowledgments: This work was financially supported by the Sichuan Veterinary Medicine and Drug Innovation Group of China Agricultural Research System (CARS-SVDIP), the Science and Technology Project of Sichuan Province (Grant Nos. 2018NZ0043 and 2018NZ0064).

Conflicts of Interest: All authors declared have no conflict of interest. 


\section{References}

1. Ley, R.E.; Peterson, D.A.; Gordon, J.I. Ecological and Evolutionary Forces Shaping Microbial Diversity in the Human Intestine. Cell 2006, 124, 837-848. [CrossRef]

2. Dethlefsen, L.; McFall-Ngai, M.; Relman, D.A. An ecological and evolutionary perspective on human-microbe mutualism and disease. Nature 2007, 449, 811. [CrossRef]

3. Round, J.L.; Mazmanian, S.K. The gut microbiota shapes intestinal immune responses during health and disease. Nat. Rev. Immunol. 2009, 9, 313. [CrossRef]

4. Flint, H.J.; Scott, K.P.; Louis, P.; Duncan, S.H. The role of the gut microbiota in nutrition and health. Nat. Rev. Gastroenterol. Hepatol. 2012, 9, 577. [CrossRef]

5. Zhu, G.; Jiang, Y.; Yao, Y.; Wu, N.; Luo, J.; Hu, M.; Tu, Y.; Xu, M. Ovotransferrin ameliorates the dysbiosis of immunomodulatory function and intestinal microbiota induced by cyclophosphamide. Food Funct. 2019, 10, 1109-1122. [CrossRef]

6. Lu, S.; Zuo, T.; Zhang, N.; Shi, H.; Liu, F.; Wu, J.; Wang, Y.; Xue, C.; Tang, Q.-J. High throughput sequencing analysis reveals amelioration of intestinal dysbiosis by squid ink polysaccharide. J. Funct. Foods 2016, 20, 506-515. [CrossRef]

7. Xie, Q.; Pan, M.; Huang, R.; Tian, X.; Tao, X.; Shah, N.P.; Wei, H.; Wan, C. Modulation of the small intestinal microbial community composition over short-term or long-term administration with Lactobacillus plantarum ZDY2013. J. Dairy Sci. 2016, 99, 6913-6921. [CrossRef]

8. Kamada, N.; Seo, S.-U.; Chen, G.Y.; Núñez, G. Role of the gut microbiota in immunity and inflammatory disease. Nat. Rev. Immunol. 2013, 13, 321. [CrossRef]

9. Hooper, L.V.; Gordon, J.I. Commensal host-bacterial relationships in the gut. Science 2001, 292, 1115-1118. [CrossRef]

10. Macpherson, A.J.; Harris, N.L. Interactions between commensal intestinal bacteria and the immune system. Nat. Rev. Immunol. 2004, 4, 478. [CrossRef]

11. Hooper, L.V.; Littman, D.R.; Macpherson, A.J. Interactions between the microbiota and the immune system. Science 2012, 336, 1268-1273. [CrossRef] [PubMed]

12. Smith, K.; McCoy, K.D.; Macpherson, A.J. Use of axenic animals in studying the adaptation of mammals to their commensal intestinal microbiota. Semin. Immunol. 2007, 19, 59-69. [CrossRef] [PubMed]

13. Mazmanian, S.K.; Round, J.L.; Kasper, D.L. A microbial symbiosis factor prevents intestinal inflammatory disease. Nature 2008, 453, 620. [CrossRef] [PubMed]

14. Ivanov, I.I.; Atarashi, K.; Manel, N.; Brodie, E.L.; Shima, T.; Karaoz, U.; Wei, D.; Goldfarb, K.C.; Santee, C.A.; Lynch, S.V. Induction of intestinal Th17 cells by segmented filamentous bacteria. Cell 2009, 139, 485-498. [CrossRef] [PubMed]

15. Atarashi, K.; Tanoue, T.; Shima, T.; Imaoka, A.; Kuwahara, T.; Momose, Y.; Cheng, G.; Yamasaki, S.; Saito, T.; Ohba, Y. Induction of colonic regulatory T cells by indigenous Clostridium species. Science 2011, 331, 337-341. [CrossRef] [PubMed]

16. Yegani, M.; Korver, D. Factors affecting intestinal health in poultry. Poult. Sci. 2008, 87, 2052-2063. [CrossRef] [PubMed]

17. Choi, J.; Kim, G.; Cha, C. Spatial heterogeneity and stability of bacterial community in the gastrointestinal tracts of broiler chickens. Poult. Sci. 2014, 93, 1942-1950. [CrossRef]

18. Sharma, J. The avian immune system. Dis. Poult. Saif. YmEd Iowa State Univ. PressAmes. 2003, 5-16.

19. Spor, A.; Koren, O.; Ley, R. Unravelling the effects of the environment and host genotype on the gut microbiome. Nat. Rev. Microbiol. 2011, 9, 279. [CrossRef]

20. Chang, C.; Lin, H. Dysbiosis in gastrointestinal disorders. Best Pract. Res. Clin. Gastroenterol. 2016, 30, 3-15. [CrossRef]

21. Deriu, E.; Boxx, G.M.; He, X.; Pan, C.; Benavidez, S.D.; Cen, L.; Rozengurt, N.; Shi, W.; Cheng, G. Influenza virus affects intestinal microbiota and secondary salmonella infection in the gut through type I interferons. PLoS Pathog. 2016, 12, e1005572. [CrossRef] [PubMed]

22. Winter, S.E.; Winter, M.G.; Xavier, M.N.; Thiennimitr, P.; Poon, V.; Keestra, A.M.; Laughlin, R.C.; Gomez, G.; $\mathrm{Wu}, \mathrm{J}$; Lawhon, S.D. Host-derived nitrate boosts growth of E. coli in the inflamed gut. Science 2013, 339, 708-711. [CrossRef] [PubMed] 
23. Barnes, E.M. The intestinal microflora of poultry and game birds during life and after storage. J. Appl. Bacteriol. 1979, 46, 407-419. [CrossRef] [PubMed]

24. Gong, J.; Si, W.; Forster, R.J.; Huang, R.; Yu, H.; Yin, Y.; Yang, C.; Han, Y. 16 S rRNA gene-based analysis of mucosa-associated bacterial community and phylogeny in the chicken gastrointestinal tracts: From crops to ceca. Fems Microbiol. Ecol. 2007, 59, 147-157. [CrossRef] [PubMed]

25. Ma, X.; Wang, Q.; Li, H.; Xu, C.; Cui, N.; Zhao, X. 16S rRNA genes Illumina sequencing revealed differential cecal microbiome in specific pathogen free chickens infected with different subgroup of avian leukosis viruses. Vet. Microbiol. 2017, 207, 195-204. [CrossRef] [PubMed]

26. Stanley, D.; Wu, S.-B.; Rodgers, N.; Swick, R.A.; Moore, R.J. Differential responses of cecal microbiota to fishmeal, Eimeria and Clostridium perfringens in a necrotic enteritis challenge model in chickens. PLoS ONE 2014, 9, e104739. [CrossRef] [PubMed]

27. Chen, C.-J.; Wu, G.-H.; Kuo, R.-L.; Shih, S.-R. Role of the intestinal microbiota in the immunomodulation of influenza virus infection. Microbes Infect. 2017, 19, 570-579. [CrossRef] [PubMed]

28. Budden, K.F.; Gellatly, S.L.; Wood, D.L.; Cooper, M.A.; Morrison, M.; Hugenholtz, P.; Hansbro, P.M. Emerging pathogenic links between microbiota and the gut-lung axis. Nat. Rev. Microbiol. 2017, 15, 55. [CrossRef] [PubMed]

29. Thorburn, A.N.; McKenzie, C.I.; Shen, S.; Stanley, D.; Macia, L.; Mason, L.J.; Roberts, L.K.; Wong, C.H.; Shim, R.; Robert, R. Evidence that asthma is a developmental origin disease influenced by maternal diet and bacterial metabolites. Nat. Commun. 2015, 6, 7320. [CrossRef]

30. Ichinohe, T.; Pang, I.K.; Kumamoto, Y.; Peaper, D.R.; Ho, J.H.; Murray, T.S.; Iwasaki, A. Microbiota regulates immune defense against respiratory tract influenza A virus infection. Proc. Natl. Acad. Sci. USA 2011, 108, 5354-5359. [CrossRef]

31. Oh, J.Z.; Ravindran, R.; Chassaing, B.; Carvalho, F.A.; Maddur, M.S.; Bower, M.; Hakimpour, P.; Gill, K.P.; Nakaya, H.I.; Yarovinsky, F. TLR5-mediated sensing of gut microbiota is necessary for antibody responses to seasonal influenza vaccination. Immunity 2014, 41, 478-492. [CrossRef] [PubMed]

32. Wu, S.; Jiang, Z.-Y.; Sun, Y.-F.; Yu, B.; Chen, J.; Dai, C.-Q.; Wu, X.-L.; Tang, X.-L.; Chen, X.-Y. Microbiota regulates the TLR7 signaling pathway against respiratory tract influenza A virus infection. Curr. Microbiol. 2013, 67, 414-422. [CrossRef] [PubMed]

33. Clarke, T.B. Early innate immunity to bacterial infection in the lung is regulated systemically by the commensal microbiota via nod-like receptor ligands. Infect. Immun. 2014, 82, 4596-4606. [CrossRef] [PubMed]

34. Fagundes, C.T.; Amaral, F.A.; Vieira, A.T.; Soares, A.C.; Pinho, V.; Nicoli, J.R.; Vieira, L.Q.; Teixeira, M.M.; Souza, D.G. Transient TLR activation restores inflammatory response and ability to control pulmonary bacterial infection in germfree mice. J. Immunol. 2012, 188, 1411-1420. [CrossRef] [PubMed]

35. Schuijt, T.J.; Lankelma, J.M.; Scicluna, B.P.; e Melo, F.d.S.; Roelofs, J.J.; de Boer, J.D.; Hoogendijk, A.J.; de Beer, R.; de Vos, A.; Belzer, C. The gut microbiota plays a protective role in the host defence against pneumococcal pneumonia. Gut 2016, 65, 575-583. [CrossRef] [PubMed]

36. McAleer, J.P.; Nguyen, N.L.; Chen, K.; Kumar, P.; Ricks, D.M.; Binnie, M.; Armentrout, R.A.; Pociask, D.A.; Hein, A.; Yu, A. Pulmonary Th17 antifungal immunity is regulated by the gut microbiome. J. Immunol. 2016, 197, 97-107. [CrossRef] [PubMed]

37. Pfeiffer, J.K.; Virgin, H.W. Transkingdom control of viral infection and immunity in the mammalian intestine. Science 2016, 351, aad5872. [CrossRef]

38. Samuelson, D.R.; Welsh, D.A.; Shellito, J.E. Regulation of lung immunity and host defense by the intestinal microbiota. Front. Microbiol. 2015, 6, 1085. [CrossRef]

39. Zhang, S.; Wei, T.; Tianv, H.; Cheng, J.; Xiao, J.; Wang, M.; Hu, Y. Small intestinal injury in mice infected with respiratory influenza A virus: Evidence for virus induced gastroenteritis. Biotechnol. Lett. 2015, 37, 1585-1592. [CrossRef]

40. Maeda, N.; Nakamura, R.; Hirose, Y.; Murosaki, S.; Yamamoto, Y.; Kase, T.; Yoshikai, Y. Oral administration of heat-killed Lactobacillus plantarum L-137 enhances protection against influenza virus infection by stimulation of type I interferon production in mice. Int. Immunopharmacol. 2009, 9, 1122-1125. [CrossRef]

41. Yitbarek, A.; Taha-Abdelaziz, K.; Hodgins, D.C.; Read, L.; Nagy, É.; Weese, J.S.; Caswell, J.L.; Parkinson, J.; Sharif, S. Gut microbiota-mediated protection against influenza virus subtype H9N2 in chickens is associated with modulation of the innate responses. Sci. Rep. 2018, 8, 13189. [CrossRef] [PubMed] 
42. Nakayama, Y.; Moriya, T.; Sakai, F.; Ikeda, N.; Shiozaki, T.; Hosoya, T.; Nakagawa, H.; Miyazaki, T. Oral administration of Lactobacillus gasseri SBT2055 is effective for preventing influenza in mice. Sci. Rep. 2014, 4, 4638. [CrossRef]

43. Sakai, F.; Hosoya, T.; Ono-Ohmachi, A.; Ukibe, K.; Ogawa, A.; Moriya, T.; Kadooka, Y.; Shiozaki, T.; Nakagawa, H.; Nakayama, Y. Lactobacillus gasseri SBT2055 induces TGF- $\beta$ expression in dendritic cells and activates TLR2 signal to produce IgA in the small intestine. PLoS ONE 2014, 9, e105370. [CrossRef] [PubMed]

44. Nishihira, J.; Nishimura, M.; Moriya, T.; Sakai, F.; Kabuki, T.; Kawasaki, Y. Lactobacillus Gasseri Potentiates Immune Response Against Influenza Virus Infection. In Immunity and Inflammation in Health and Disease; Elsevier: Amsterdam, The Netherland, 2018; pp. 249-255.

45. Denny, J.E.; Powell, W.L.; Schmidt, N.W. Local and long-distance calling: Conversations between the gut microbiota and intra-and extra-gastrointestinal tract infections. Front. Cell. Infect. Microbiol. 2016, 6, 41. [CrossRef] [PubMed]

46. Dunn, J.R.; Gimeno, I.M. Current status of Marek's disease in the United States and worldwide based on a questionnaire survey. Avian Dis. 2013, 57, 483-490. [CrossRef] [PubMed]

47. Couteaudier, M.; Denesvre, C. Marek's disease virus and skin interactions. Vet. Res. 2014, 45, 36. [CrossRef] [PubMed]

48. Witter, R.; Schat, K. Diseases of Poultry, Chapter 15: Subchapter-Marek's Disease. In Disease of Poltry; Agricultural Research Service U.S. Department of Agriculture: Urbana, IL, USA, 2003; pp. 407-465.

49. Calnek, B.; Schat, K.; Ross, L.; Chen, C.L. Further characterization of marek's disease virus-infected lymphocytes. II. In vitro infection. Int. J. Cancer 1984, 33, 399-406. [CrossRef]

50. Read, A.F.; Baigent, S.J.; Powers, C.; Kgosana, L.B.; Blackwell, L.; Smith, L.P.; Kennedy, D.A.; Walkden-Brown, S.W.; Nair, V.K. Imperfect vaccination can enhance the transmission of highly virulent pathogens. PLoS Biol. 2015, 13, e1002198. [CrossRef]

51. Witter, R. Increased virulence of Marek's disease virus field isolates. Avian Dis. 1997, 41, 149-163. [CrossRef]

52. Nair, V. Evolution of Marek's disease-a paradigm for incessant race between the pathogen and the host. Vet. J. 2005, 170, 175-183. [CrossRef]

53. Kamaldeep, P.; Sharma, C.; Narang, G. Occurrence of Marek's disease in vaccinated poultry flocks of Haryana (India). Int. J. Poult. Sci. 2007, 6, 372-377.

54. Arulmozhi, A.; Saravanan, S.; Mohan, B.; Balasubramaniam, G. Marek's disease in vaccinated poultry flocks in and around Namakkal region of Tamil Nadu. Indian J. Vet. Pathol. 2011, 35, 45-47.

55. Muniyellappa, H.; Satyanarayana, M.; Isloor, S.; Gowda, N.S. Marek's disease outbreak among vaccinated commercial layer flocks in the mining area of Karnataka, India. Vet. Rec. 2013, 172, 452. [CrossRef] [PubMed]

56. McPherson, M.; Delany, M. Virus and host genomic, molecular, and cellular interactions during Marek's disease pathogenesis and oncogenesis. Poult. Sci. 2016, 95, 412-429. [CrossRef] [PubMed]

57. Nair, V. Latency and tumorigenesis in Marek's disease. Avian Dis. 2013, 57, 360-365. [CrossRef] [PubMed]

58. Lillehoj, H.S.; Trout, J.M. Avian gut-associated lymphoid tissues and intestinal immune responses to Eimeria parasites. Clin. Microbiol. Rev. 1996, 9, 349-360. [CrossRef]

59. Arega, A.M. Review on infectious Bursal disease: Threat for Ethiopian poultry industry. IJALS 2018, 11, 52-65. [CrossRef]

60. Khan, R.S.A.; Sajid, S.; Habib, M.; Ali, W.; Shah, M.S.-u.-D.; Sarfraz, M. History of Gumboro (infectious bursal disease) in Pakistan. Saudi Pharm. J. 2017, 25, 453-459. [CrossRef]

61. Ingrao, F.; Rauw, F.; Lambrecht, B.; van den Berg, T. Infectious bursal disease: A complex host-pathogen interaction. Dev. Comp. Immunol. 2013, 41, 429-438. [CrossRef]

62. Giambrone, J.; Donahoe, J.; Dawe, D.; Eidson, C. Specific suppression of the bursa-dependent immune system of chicks with infectious bursal disease virus. Am. J. Vet. Res. 1977, 38, 581-583.

63. Delmas, B.; Kibenge, F.S.B.; Leon, J.C.; Mundt, E.; Vakaharia, V.N.; Wu, J.L. Birnaviridae. In Virus Virus Taxonomy. 8th Report ICTV; Fauquet, C.M., Mayo, M.A., Maniloff, J., Desselberger, U., Ball, L.A., Eds.; Elsevier Academic Press: San Diego, CA, USA, 2005; pp. 561-569.

64. Brown, M.D.; Skinner, M.A. Coding sequences of both genome segments of a European 'very virulent'infectious bursal disease virus. Virus Res. 1996, 40,1-15. [CrossRef]

65. Müller, H.; Islam, M.R.; Raue, R. Research on infectious bursal disease - the past, the present and the future. Vet. Microbiol. 2003, 97, 153-165. [CrossRef] [PubMed] 
66. Ye, C.; Wang, Y.; Zhang, E.; Han, X.; Yu, Z.; Liu, H. VP1 and VP3 are required and sufficient for translation initiation of uncapped infectious bursal disease virus genomic double-stranded RNA. J. Virol. 2018, 92, e01345-17. [CrossRef] [PubMed]

67. Hoerr, F.J. Clinical aspects of immunosuppression in poultry. Avian Dis. 2010, 54, 2-15. [CrossRef] [PubMed]

68. Balamurugan, V.; Kataria, J. Economically important non-oncogenic immunosuppressive viral diseases of chicken-current status. Vet. Res. Commun. 2006, 30, 541-566. [CrossRef] [PubMed]

69. Jackwood, D.J. Advances in vaccine research against economically important viral diseases of food animals: Infectious bursal disease virus. Vet. Microbiol. 2017, 206, 121-125. [CrossRef] [PubMed]

70. Käufer, I.; Weiss, E. Significance of bursa of Fabricius as target organ in infectious bursal disease of chickens. Infect. Immun. 1980, 27, 364-367. [PubMed]

71. Turmagambetova, A.S.; Alexyuk, M.S.; Bogoyavlenskiy, A.P.; Linster, M.; Alexyuk, P.G.; Zaitceva, I.A.; Smith, G.J.; Berezin, V.E. Monitoring of Newcastle disease virus in environmental samples. Arch. Virol. 2017, 162, 2843-2846. [CrossRef] [PubMed]

72. Maes, P.; Amarasinghe, G.K.; Ayllón, M.A.; Basler, C.F.; Bavari, S.; Blasdell, K.R.; Briese, T.; Brown, P.A.; Bukreyev, A.; Balkema-Buschmann, A. Taxonomy of the order Mononegavirales: Second update 2018. Arch. Virol. 2019, 164, 1233-1244. [CrossRef] [PubMed]

73. Li, Y.P. ERIC-PCR Based Fingerprint to Analyze the Structural Features of Intestinal Microbial Communities of Chicks Infected with Salmonella gallinarum, Newcastle Disease Virus and the Healthy Chicks. Ph.D. Thesis, Sichuan Agricultural University, Sichuan, China, 2007.

74. Post, J.; Burt, D.W.; Cornelissen, J.B.; Broks, V.; van Zoelen, D.; Peeters, B.; Rebel, J.M. Systemic virus distribution and host responses in brain and intestine of chickens infected with low pathogenic or high pathogenic avian influenza virus. Virol. J. 2012, 9, 61. [CrossRef] [PubMed]

75. Abt, M.C.; Osborne, L.C.; Monticelli, L.A.; Doering, T.A.; Alenghat, T.; Sonnenberg, G.F.; Paley, M.A.; Antenus, M.; Williams, K.L.; Erikson, J. Commensal bacteria calibrate the activation threshold of innate antiviral immunity. Immunity 2012, 37, 158-170. [CrossRef] [PubMed]

76. Yitbarek, A.; Alkie, T.; Taha-Abdelaziz, K.; Astill, J.; Rodriguez-Lecompte, J.; Parkinson, J.; Nagy, É.; Sharif, S. Gut microbiota modulates type I interferon and antibody-mediated immune responses in chickens infected with influenza virus subtype H9N2. Benef. Microbes 2018, 9, 417-427. [CrossRef] [PubMed]

77. Yan, N.; Chen, Z.J. Intrinsic antiviral immunity. Nat. Immunol. 2012, 13, 214. [CrossRef] [PubMed]

78. McNab, F.; Mayer-Barber, K.; Sher, A.; Wack, A.; O'garra, A. Type I interferons in infectious disease. Nat. Rev. Immunol. 2015, 15, 87. [CrossRef] [PubMed]

79. Barjesteh, N.; Shojadoost, B.; Brisbin, J.T.; Emam, M.; Hodgins, D.C.; Nagy, É.; Sharif, S. Reduction of avian influenza virus shedding by administration of Toll-like receptor ligands to chickens. Vaccine 2015, 33, 4843-4849. [CrossRef]

80. Hernández, P.P.; Mahlakõiv, T.; Yang, I.; Schwierzeck, V.; Nguyen, N.; Guendel, F.; Gronke, K.; Ryffel, B.; Hölscher, C.; Dumoutier, L. Interferon- $\lambda$ and interleukin 22 act synergistically for the induction of interferon-stimulated genes and control of rotavirus infection. Nat. Immunol. 2015, 16, 698. [CrossRef] [PubMed]

81. Gimeno Brias, S.; Stack, G.; Stacey, M.A.; Redwood, A.J.; Humphreys, I.R. The role of IL-22 in viral infections: Paradigms and paradoxes. Front. Immunol. 2016, 7, 211. [CrossRef]

82. Yuk, S.-S.; Lee, D.-H.; Park, J.-K.; Tseren-Ochir, E.-O.; Kwon, J.-H.; Noh, J.-Y.; Lee, J.-B.; Park, S.-Y.; Choi, I.-S.; Song, C.-S. Pre-immune state induced by chicken interferon gamma inhibits the replication of H1N1 human and H9N2 avian influenza viruses in chicken embryo fibroblasts. Virol. J. 2016, 13, 71. [CrossRef]

83. Xia, C.; Liu, J.; Wu, Z.; Lin, C.; Wang, M. The interferon- $\alpha$ genes from three chicken lines and its effects on H9N2 influenza viruses. Anim. Biotechnol. 2004, 15, 77-88. [CrossRef]

84. Cornelissen, J.; Post, J.; Peeters, B.; Vervelde, L.; Rebel, J. Differential innate responses of chickens and ducks to low-pathogenic avian influenza. Avian Pathol. 2012, 41, 519-529. [CrossRef]

85. Barbour, E.K.; Mastori, F.A.; Nour, A.A.; Shaib, H.A.; Jaber, L.S.; Yaghi, R.H.; Sabra, A.; Sleiman, F.T.; Sawaya, R.K.; Niedzwieck, A. Standardisation of a new model of H9N2/Escherichia coli challenge in broilers in the Lebanon. Vet. Ital. 2009, 45, 317-322. [PubMed]

86. Li, H.; Liu, X.; Chen, F.; Zuo, K.; Wu, C.; Yan, Y.; Chen, W.; Lin, W.; Xie, Q. Avian influenza virus subtype H9N2 affects intestinal microbiota, barrier structure injury, and inflammatory intestinal disease in the chicken ileum. Viruses 2018, 10, 270. [CrossRef] [PubMed] 
87. Oakley, B.B.; Kogut, M.H. Spatial and temporal changes in the broiler chicken cecal and fecal microbiomes and correlations of bacterial taxa with cytokine gene expression. Front. Vet. Sci. 2016, 3, 11. [CrossRef] [PubMed]

88. Wang, J.; Li, F.; Wei, H.; Lian, Z.-X.; Sun, R.; Tian, Z. Respiratory influenza virus infection induces intestinal immune injury via microbiota-mediated Th17 cell-dependent inflammation. J. Exp. Med. 2014, 211, 2397-2410. [CrossRef] [PubMed]

89. Keita, å.v.; Söderholm, J.D. The intestinal barrier and its regulation by neuroimmune factors. Neurogastroenterol. Motil. 2010, 22, 718-733. [CrossRef] [PubMed]

90. Fagarasan, S. Intestinal IgA synthesis: A primitive form of adaptive immunity that regulates microbial communities in the gut. In Gut-Associated Lymphoid Tissues; Springer: Berlin, Germany, 2006; pp. 137-153.

91. Burkholder, K.; Thompson, K.; Einstein, M.; Applegate, T.; Patterson, J. Influence of stressors on normal intestinal microbiota, intestinal morphology, and susceptibility to Salmonella enteritidis colonization in broilers. Poult. Sci. 2008, 87, 1734-1741. [CrossRef] [PubMed]

92. Chappell, L.; Kaiser, P.; Barrow, P.; Jones, M.A.; Johnston, C.; Wigley, P. The immunobiology of avian systemic salmonellosis. Vet. Immunol. Immunopathol. 2009, 128, 53-59. [CrossRef]

93. Hansson, G.C. Role of mucus layers in gut infection and inflammation. Curr. Opin. Microbiol. 2012, 15, 57-62. [CrossRef]

94. Taupin, D.; Kinoshita, K.; Podolsky, D. Intestinal trefoil factor confers colonic epithelial resistance to apoptosis. Proc. Natl. Acad. Sci. USA 2000, 97, 799-804. [CrossRef]

95. Sands, B.; Podolsky, D. The trefoil peptide family. Annu. Rev. Physiol. 1996, 58, 253-273. [CrossRef]

96. Furuse, M.; Fujita, K.; Hiiragi, T.; Fujimoto, K.; Tsukita, S. Claudin-1 and-2: Novel integral membrane proteins localizing at tight junctions with no sequence similarity to occludin. J. Cell Biol. 1998, 141, 1539-1550. [CrossRef] [PubMed]

97. Gumbiner, B.; Lowenkopf, T.; Apatira, D. Identification of a 160-kDa polypeptide that binds to the tight junction protein ZO-1. Proc. Natl. Acad. Sci. USA 1991, 88, 3460-3464. [CrossRef] [PubMed]

98. Willott, E.; Balda, M.S.; Fanning, A.S.; Jameson, B.; Van Itallie, C.; Anderson, J.M. The tight junction protein ZO-1 is homologous to the Drosophila discs-large tumor suppressor protein of septate junctions. Proc. Natl. Acad. Sci. USA 1993, 90, 7834-7838. [CrossRef] [PubMed]

99. Haskins, J.; Gu, L.; Wittchen, E.S.; Hibbard, J.; Stevenson, B.R. ZO-3, a novel member of the MAGUK protein family found at the tight junction, interacts with ZO-1 and occludin. J. Cell Biol. 1998, 141, 199-208. [CrossRef] [PubMed]

100. Befus, A.D.; Johnston, N.; Leslie, G.; Bienenstock, J. Gut-associated lymphoid tissue in the chicken. I. Morphology, ontogeny, and some functional characteristics of Peyer's patches. J. Immunol. 1980, 125, 2626-2632.

101. Liebler-Tenorio, E.M.; Pabst, R. MALT structure and function in farm animals. Vet. Res. 2006, 37, $257-280$. [CrossRef] [PubMed]

102. Vindigni, S.M.; Zisman, T.L.; Suskind, D.L.; Damman, C.J. The intestinal microbiome, barrier function, and immune system in inflammatory bowel disease: A tripartite pathophysiological circuit with implications for new therapeutic directions. Ther. Adv. Gastroenterol. 2016, 9, 606-625. [CrossRef]

103. Ruby, T.; Whittaker, C.; Withers, D.R.; Chelbi-Alix, M.K.; Morin, V.; Oudin, A.; Young, J.R.; Zoorob, R. Transcriptional profiling reveals a possible role for the timing of the inflammatory response in determining susceptibility to a viral infection. J. Virol. 2006, 80, 9207-9216. [CrossRef]

104. Li, Z.; Wang, Y.; Xue, Y.; Li, X.; Cao, H.; Zheng, S.J. Critical role for voltage-dependent anion channel 2 in infectious bursal disease virus-induced apoptosis in host cells via interaction with VP5. J. Virol. 2012, 86, 1328-1338. [CrossRef]

105. Li, L.; Kubasová, T.; Rychlik, I.; Hoerr, F.J.; Rautenschlein, S. Infectious bursal disease virus infection leads to changes in the gut associated-lymphoid tissue and the microbiota composition. PLOS ONE 2018, 13, e0192066. [CrossRef]

106. Frank, D.N.; Amand, A.L.S.; Feldman, R.A.; Boedeker, E.C.; Harpaz, N.; Pace, N.R. Molecular-phylogenetic characterization of microbial community imbalances in human inflammatory bowel diseases. Proc. Natl. Acad. Sci. USA 2007, 104, 13780-13785. [CrossRef] [PubMed]

107. Sokol, H.; Pigneur, B.; Watterlot, L.; Lakhdari, O.; Bermúdez-Humarán, L.G.; Gratadoux, J.-J.; Blugeon, S.; Bridonneau, C.; Furet, J.-P.; Corthier, G. Faecalibacterium prausnitzii is an anti-inflammatory commensal 
bacterium identified by gut microbiota analysis of Crohn disease patients. Proc. Natl. Acad. Sci. USA 2008, 105, 16731-16736. [CrossRef] [PubMed]

108. Willing, B.; Halfvarson, J.; Dicksved, J.; Rosenquist, M.; Jänerot, G.; Engstrand, L.; Tysk, C.; Jansson, J.K. Twin studies reveal specific imbalances in the mucosa-associated microbiota of patients with ileal Crohns disease. Inflamm. Bowel Dis. 2009, 15, 653-660. [CrossRef] [PubMed]

109. Christophersen, C.; Morrison, M.; Conlon, M. Overestimation of the abundance of sulfate-reducing bacteria in human feces by quantitative PCR targeting the Desulfovibrio 16S rRNA gene. Appl. Env. Microbiol. 2011, 77, 3544-3546. [CrossRef]

110. Blachier, F.; Davila, A.-M.; Mimoun, S.; Benetti, P.-H.; Atanasiu, C.; Andriamihaja, M.; Benamouzig, R.; Bouillaud, F.; Tomé, D. Luminal sulfide and large intestine mucosa: Friend or foe? Amino Acids 2010, 39, 335-347. [CrossRef] [PubMed]

111. Duncan, S.H.; Hold, G.L.; Harmsen, H.J.; Stewart, C.S.; Flint, H.J. Growth requirements and fermentation products of Fusobacterium prausnitzii, and a proposal to reclassify it as Faecalibacterium prausnitzii gen. nov., comb. nov. Int. J. Syst. Evol. Microbiol. 2002, 52, 2141-2146. [PubMed]

112. Van Deun, K.; Pasmans, F.; van Immerseel, F.; Ducatelle, R.; Haesebrouck, F. Butyrate protects Caco-2 cells from Campylobacter jejuni invasion and translocation. Br. J. Nutr. 2008, 100, 480-484. [CrossRef] [PubMed]

113. Li, L.; Pielsticker, C.; Han, Z.; Kubasová, T.; Rychlik, I.; Kaspers, B.; Rautenschlein, S. Infectious bursal disease virus inoculation infection modifies Campylobacter jejuni-host interaction in broilers. Gut Pathog. 2018, 10, 13. [CrossRef] [PubMed]

114. Subler, K.A.; Mickael, C.S.; Jackwood, D.J. Infectious bursal disease virus-induced immunosuppression exacerbates Campylobacter jejuni colonization and shedding in chickens. Avian Dis. 2006, 50, 179-184. [CrossRef]

115. MacDonald, T.T.; Monteleone, G. Immunity, inflammation, and allergy in the gut. Science 2005, 307, 1920-1925. [CrossRef]

116. Lukert, P.D.; Saif, Y.M. Infectious Bursal Disease, 10th ed.; Calnek, B.W., Barnes, H.J., Beard, C.W., McDougald, L.R., Saif, Y.M., Eds.; Iowa State University Press: Ames, IA, USA, 1997; pp. 721-738.

117. Bautista, D.; Elankumaran, S.; Heckert, R. Effect of a variant infectious bursal disease virus (E/Del) on Salmonella typhimurium infection in commercial broiler chickens. Avian Dis. 2004, 48, 361-369. [CrossRef] [PubMed]

118. Wyeth, P. Effect of infectious bursal disease on the response of chickens to Salmonella typhimurium and Escherichia coli infections. Vet. Rec. 1975, 96, 238-243. [CrossRef] [PubMed]

119. Arafat, N.; Eladl, A.H.; Mahgoub, H.; El-Shafei, R.A. Effect of infectious bursal disease (IBD) vaccine on Salmonella Enteritidis infected chickens. Vaccine 2017, 35, 3682-3689. [CrossRef] [PubMed]

120. Naseem, S.; Rahman, S.; Shafee, M.; Sheikh, A.; Khan, A. Immunomodulatory and growth-promoting effect of a probiotic supplemented in the feed of broiler chicks vaccinated against infectious bursal disease. Braz. J. Poult. Sci. 2012, 14, 109-113. [CrossRef]

121. Witter, R.; Gimeno, I.; Reed, W.; Bacon, L. An acute form of transient paralysis induced by highly virulent strains of Marek's disease virus. Avian Dis. 1999, 43, 704-720. [CrossRef] [PubMed]

122. Calnek, B.; Harris, R.; Buscaglia, C.; Schat, K.; Lucio, B. Relationship between the immunosuppressive potential and the pathotype of Marek's disease virus isolates. Avian Dis. 1998, 42, 124-132. [CrossRef] [PubMed]

123. Perumbakkam, S.; Hunt, H.D.; Cheng, H.H. Marek's disease virus influences the core gut microbiome of the chicken during the early and late phases of viral replication. Fems Microbiol. Ecol. 2014, 90, 300-312. [CrossRef] [PubMed]

124. Giansanti, F.; Giardi, M.F.; Massucci, M.T.; Botti, D.; Antonini, G. Ovotransferrin expression and release by chicken cell lines infected with Marek's disease virus. Biochem. Cell Biol. 2007, 85, 150-155. [CrossRef] [PubMed]

125. Giansanti, F.; Leboffe, L.; Angelucci, F.; Antonini, G. The nutraceutical properties of ovotransferrin and its potential utilization as a functional food. Nutrients 2015, 7, 9105-9115. [CrossRef]

126. Giardi, M.F.; La Torre, C.; Giansanti, F.; Botti, D. Effects of transferrins and cytokines on nitric oxide production by an avian lymphoblastoid cell line infected with Marek's disease virus. Antivir. Res. 2009, 81, $248-252$. [CrossRef] 
127. Atarashi, K.; Tanoue, T.; Oshima, K.; Suda, W.; Nagano, Y.; Nishikawa, H.; Fukuda, S.; Saito, T.; Narushima, S.; Hase, K. T reg induction by a rationally selected mixture of Clostridia strains from the human microbiota. Nature 2013, 500, 232. [CrossRef] [PubMed]

128. Perumbakkam, S.; Hunt, H.D.; Cheng, H.H. Differences in CD8 $\alpha \alpha$ and cecal microbiome community during proliferation and late cytolytic phases of Marek's disease virus infection are associated with genetic resistance to Marek's disease. Fems Microbiol. Ecol. 2016, 92, fiw188. [CrossRef] [PubMed]

129. Liu, C.; Finegold, S.M.; Song, Y.; Lawson, P.A. Reclassification of Clostridium coccoides, Ruminococcus hansenii, Ruminococcus hydrogenotrophicus, Ruminococcus luti, Ruminococcus productus and Ruminococcus schinkii as Blautia coccoides gen. nov., comb. nov., Blautia hansenii comb. nov., Blautia hydrogenotrophica comb. nov., Blautia luti comb. nov., Blautia producta comb. nov., Blautia schinkii comb. nov. and description of Blautia wexlerae sp. nov., isolated from human faeces. Int. J. Syst. Evol. Microbiol. 2008, 58, 1896-1902. [PubMed]

130. Biddle, A.; Stewart, L.; Blanchard, J.; Leschine, S. Untangling the genetic basis of fibrolytic specialization by Lachnospiraceae and Ruminococcaceae in diverse gut communities. Diversity 2013, 5, 627-640. [CrossRef]

131. Wages, D.P. Streptococcosis. In Diseases of Poultry, 11th ed.; Saif, Y.M., Barnes, H.J., Glisson, J.R., Fadly, A.M., McDougald, L.R., Swayne, D.E., Eds.; Iowa State Press: Ames, IA, USA, 2003; p. 805812.

132. Wakamatsu, N.; King, D.; Kapczynski, D.; Seal, B.; Brown, C. Experimental pathogenesis for chickens, turkeys, and pigeons of exotic Newcastle disease virus from an outbreak in California during 2002-2003. Vet. Pathol. 2006, 43, 925-933. [CrossRef] [PubMed]

133. Brown, V.R.; Bevins, S.N. A review of virulent Newcastle disease viruses in the United States and the role of wild birds in viral persistence and spread. Vet. Res. 2017, 48, 68. [CrossRef] [PubMed]

134. Baron, S.; Buckler, C.E. Circulating interferon in mice after intravenous injection of virus. Science 1963, 141, 1061-1063. [CrossRef] [PubMed]

135. Huang, K.-Y.; Landay, M.E. Enhancement of the lethal effects of endotoxins by interferon inducers. J. Bacteriol. 1969, 100, 1110.

136. Zhang, L.; Wang, G.; Yu, H.; Wang, J.; Wang, S.; Jia, Y.; Yu, Y.; Xu, J. First report of human infection by Rhodoplanes sp., Alphaproteobacteria in China. Asian Pac. J. Trop. Med. 2011, 4, 248-250. [CrossRef]

137. Cui, N.; Huang, X.; Kong, Z.; Huang, Y.; Huang, Q.; Yang, S.; Zhang, L.; Xu, C.; Zhang, X.; Cui, Y. Newcastle disease virus infection interferes with the formation of intestinal microflora in newly hatched specific-pathogen-free chicks. Front. Microbiol. 2018, 9, 900. [CrossRef]

138. Girardin, H.; Albagnac, C.; Dargaignaratz, C.; Nguyen-The, C.; Carlin, F. Antimicrobial activity of foodborne Paenibacillus and Bacillus spp. against Clostridium botulinum. J. Food Prot. 2002, 65, 806-813. [CrossRef] [PubMed]

139. Passera, A.; Venturini, G.; Battelli, G.; Casati, P.; Penaca, F.; Quaglino, F.; Bianco, P.A. Competition assays revealed Paenibacillus pasadenensis strain R16 as a novel antifungal agent. Microbiol. Res. 2017, 198, 16-26. [CrossRef] [PubMed]

(C) 2019 by the authors. Licensee MDPI, Basel, Switzerland. This article is an open access article distributed under the terms and conditions of the Creative Commons Attribution (CC BY) license (http://creativecommons.org/licenses/by/4.0/). 